Prego R, Caetano M, Bernardez P, Brito P, Ospina-Alvarez N, Vale C (2012) Rare earth elements in coastal sediments of the Northern Galician Shelf: influence of geological features. Continental Shelf Research 35:75-85

\title{
RARE EARTH ELEMENTS IN COASTAL SEDIMENTS OF THE NORTHERN GALICIAN SHELF: INFLUENCE OF GEOLOGICAL FEATURES
}

\author{
Ricardo Prego ${ }^{a}$, Miguel Caetano ${ }^{b}$, Patricia Bernárdez ${ }^{a}$, Pedro Brito $^{b}$, Natalia Ospina-Alvarez ${ }^{a}$ \\ and Carlos Vale ${ }^{b}$ \\ ${ }^{a}$ Marine Research Institute (CSIC), Av. Eduardo Cabello, 6. E-36208 Vigo, Spain \\ ${ }^{\mathrm{b}}$ IPIMAR/National Institute of Biological Resources, Av. Brasília, 1449-006 Lisbon, Portugal \\ * Corresponding author; e-mail: prego@iim.csic.es; phone: +34986231930; fax: +34986292762
}

Abstract. The Northern coast of Galicia, NW Iberian Peninsula, exhibits a variety of geological features: Ortegal allochthonous complex, Ollo-de-Sapo autochthonous domain and massifs of Bares, Barqueiro and San-Ciprian. In order to examine the influence of terrestrial lithologies on coastal sediments, 103 samples were collected in the Rias of Ortigueira, Barqueiro and Viveiro, their neighbouring shelf and the estuaries of Mera, Sor and Landro rivers. Aluminium, Fe, Sc, particulate inorganic and organic carbon and rare earth elements (REE) were determined in the $<2$ $\mathrm{mm}$ fraction. In addition, calcite, muscovite, quartz and riebeckite minerals were identified and quantified in 33 selected samples. The distributions of riebeckite and Fe reflect the influence of Ortegal complex on the coastal areas around the Cape Ortegal. The highest concentrations of $\Sigma$ REE were found in fine sediments from confined inner parts of the Rias (up to $233 \mathrm{mg} \cdot \mathrm{kg}^{-1}$ ), while most of the sands contained $11-70 \mathrm{mg} \cdot \mathrm{kg}^{-1}$. $\Sigma \mathrm{REE}$ normalized to European Shale (ES) highlights the relative abundance of lanthanides $\left(\Sigma R E_{N}>6\right)$ near Cape Ortegal and the innermost ria zones. The ratio between light and heavy REE $(\mathrm{L} / \mathrm{H})$ showed lower values (4-11) around Cape Ortegal and the shelf while higher ratios (15-23) were detected in west of the Cape Estaca-de-Bares and in the inner Viveiro Ria due to elevated contributions of $\mathrm{La}$ and $\mathrm{Ce}$. The $\mathrm{L} / \mathrm{H}$ values normalized to ES reflects the importance of HREE in the adjacent area to Ortegal Complex $\left(L_{N} / H_{N}<0.8\right)$ and the LREE $\left(\mathrm{L}_{N} / \mathrm{H}_{\mathrm{N}}>1.4\right)$ in the inner estuaries and west Cape Estaca-de-Bares. The highest REE individual ES normalised were measured in fine-grained sediments of the Mera and Sor estuaries. Sediments from the eastern shelf of Cape Ortegal presented enhanced ratios only for HREE. These results indicate that distribution of REE in the northern Galician region is highly depending on the neighbouring lithological pattern, contrasting with the situation found in the western Galician shelf and the Bay of Biscay. Lanthanides can, thus, provide a useful tool to follow the sediment pathway in the land-sea boundary zones, denoting continental geochemical imprint or fluvial outputs accordingly to the existing hydrological and geological conditions.

Keywords: lanthanide, sediment, estuary, ria, Galicia, NW Spain.

Cliç here to view linked References 


\section{INTRODUCTION}

Rare earth elements (REE) have been used to trace natural processes in marine environment. Firstly, Haskin and Gehl (1962), Goldberg et al. (1963) and Wildeman and Haskin (1963) pointed out the interest of REE in early diagenetic researches in pelagic sediments. Later, Ronov et al. (1967) and Piper (1974) emphasized the role of REE to ascertain the sediment pathways. Biogeochemical cycling of REE has been studied in rivers, estuaries and continental shelves (Elderfield et al., 1990; Sholkovitz, 1993; and Ramesh, 1999; Nozaki et al., 2000). Rare earth elements have been reported as geochemical indicator related to anthropogenic activities (Olmez et al., 1991; Ridgway et al., 2003; Borrego et al., 2004). Lanthanides are used in industrial processes and consequently anomalous REE concentrations have been reported in terrestrial waters, and in river and marine sediments (Olmez et al., 1991; Protano and Riccobono, 2002; Borrego et al., 2004; Kulaksiz and Bau, 2007).

The advantage of REE applicability in marine geochemistry is their chemical fractionation and coherent behaviour during weathering (Dubinin, 2004; Leybourne and Johannesson, 2008). Lanthanides applicability ranged from studies of particle-water interactions in estuarine systems due to REE affinity to freshly formed iron and manganese hydroxides (Bayon et al., 2004; Marmolejo-Rodríguez et al., 2007), transport and provenance of sediments in coastal areas due to the low anthropogenic inputs to mitigate the natural sources (Vital et al., 1999; Munksgaard et al., 2003; Xu et al., 2009; Prego et al., 2009) and to geochemical processes in hydrothermal spots (Olivarez and Owen, 1989; Bortnikov et al., 2008).

Various works describe the lithological features and tectonic details of continental allochthonous complexes in the northwest of the Iberian Peninsula: Ortegal-Ordes, Malpica-Tuy, Brangança and Morais ophiolitic units (Ortega and Gil-Ibarguchi, 1990; Pin et al., 2002). Moreover, the terrestrial contribution of Miño River (Gouveia et al., 1993), Duero River (Araújo et al., 2002) and the Ria of Vigo (Prego et al., 2009; Caetano et al., 2009) to coastal mud patches has also been assesed. The REE composition of the weathering material from the Galiñeiro orthogneissic 
Complex has been determinant to trace the imprint of river-derived sediments (Prego et al., 2009). In the Bay of Biscay, REE was only tackled in order to identify the continental sources to the shelf sediments due to the Loire, Gironde and Adour load (Joaunneau et al., 1998) and REE mobility in the deep sediments (Chaillou et al., 2006).

The northern Galicia region is composed by different continental geological domains, such as the allochthonous Ortegal Complex and the autochthonous of the Ollo-de-Sapo Domain. Their influence on coastal sediments has not been documented. In accordance with these geological features it may be hypothesised that the lanthanide distribution in sediments of that coastal region may differ depending on the land-sea boundary zone. Therefore, three objectives were set: (a) to establish baseline of REE data in river and coastal sediments from the Northern Galician, (b) to link the REE patterns in the coastal sediments with the geochemical characteristics of the landmass, and (c) to assess the continental source of lithogenic component in the sediments using the REE pattern as geochemical tracer.

\section{MATERIAL AND METHODS}

\subsection{The study area}

The northern coast of Galicia $\left(7^{\circ} 30^{\prime}-7^{\circ} 55^{\prime} \mathrm{W}\right.$; Figure 1$)$ includes the Rias of Ortigueira, Barqueiro and Viveiro, designated as Northern Galician Rias according to the tectonic classification of Torre Enciso (1958). The surface areas of the Rias of Ortigueira, Barqueiro and Viveiro are 38,10 and $27 \mathrm{~km}^{2}$, respectively, considering the 30-m depth isobath as the ria-shelf boundary. These three rias are north or north-eastward oriented, mesotidal systems dominated by marine processes in from the inlets to the middle parts (Alvarez et al., 2010; Ospina-Alvarez et al., 2010). The inner parts are shallows (Evans and Prego, 2003), with extensive marshlands and well-developed beach barriers forming mouth complexes (Lorenzo et al., 2007). The Ria of Ortigueira, the western of the studied system, is an incised valley between Cape Ortegal and Cape Estaca-de-Bares. The main freshwater source is the Mera River with a fluvial basin covering 126 
$\mathrm{km}^{2}$ and annual average flow of $6.0 \mathrm{~m}^{3} \cdot \mathrm{s}^{-1}$. Eastern of Cape Estaca-de-Bares is located the Ria of Barqueiro which receives as the main tributary the Sor River $\left(202 \mathrm{~km}^{2} ; 15.2 \mathrm{~m}^{3} \cdot \mathrm{s}^{-1}\right)$. The Ria of Viveiro is located further East and receives in the inner most zone the Landro River $\left(271 \mathrm{~km}^{2} ; 9.3\right.$ $\left.\mathrm{m}^{3} \cdot \mathrm{s}^{-1}\right)$. The annually discharge of suspended solids into the Bay of Biscay by Mera, Sor and Landro rivers accounts only approximately $0.5 \%$ of total amount entering the Bay (Prego et al., 2008).

The Northern Rias are located in a region with contrasting geological characteristics (Fig. 1). The Ortegal allochthonous complex, located at the west of the Ria of Ortigueira, exposes abundant ultramafic rocks and metaigneous granulites, lower metamorphic facies with pyroxenes, eclogites, amphibolite and serpentinites (Gil-lbarguchi et al., 1990; Peucat et al., 1990). The Ollo-de-Sapo autochthonous domain is characterized by metamorphic rock, mainly gneisses (IGME, 1977; Aparicio et al, 1987). At the east margin of the Ria of Viveiro are the granitic massifs of San-Ciprian (Capdevila, 1969), together with the Villalba Series (shale, sandstone and gneiss). The surrounding area of the Ria of Barqueiro is mainly composed by granite, the Barqueiro Massif, that is similar to the San-Ciprian and both rich in two-micas granite (IGME, 1977). In the southern boundary of Barqueiro Massif are present white quartz veins NWNoriented (quartz exploitation mine; Mirre, 1990). Moreover, in this ria it can found the Bares Massif, a discordant, elongated intrusion of reduced dimensions $\left(5 \mathrm{~km}^{2}\right)$ made up of granodiorite, and biotite (Ortega and Gil-Ibarguchi, 1990). Following this geological patterns the fluvial basin of Mera displays metamorphic rocks mainly, with a lithology composed by gneiss and metasediments, from the Ollo-de-Sapo Domain, shale, quartzite (Moeche Unit) and gneisses bands (viz. Cariño with gneiss and eclogite), which form a part of the Ortegal Complex. The basins of Baleo $\left(53 \mathrm{~km}^{2}\right)$ and Sor comprise mostly gneiss and schist (Ollo-de-Sapo Domain). The basin of the Landro River covers a mixed area mainly makes up granitic rocks being part of the Manto-deMondoñedo Domain (IGME, 1977).

\subsection{Sediment sampling}


One hundred and three samples of surface sediment were obtained in the three rias and adjoining continental shelf (Fig.1): 36 in Ortigueira, 29 in Barqueiro), 23 in Viveiro, and 15 offshore the rias). Sediments from the rias were sampled onboard the R/V Lura (July 2007), using small boats in the estuarine areas (July 2007) and onboard the R/V Mytilus in the adjacent coastal zone (May, 2008). A 30-L and 5-L Van Veen grabs and a Bouma type box corer $\left(1.75 \mathrm{dm}^{2}\right)$ were used. In the intertidal areas sediments were sampled by hand. The uppermost sediment $(0-1 \mathrm{~cm})$ was collected with a plastic spatula, stored in pre-cleaned LDPE vials and kept at $4^{\circ} \mathrm{C}$. Sediment samples were oven dried at $50^{\circ} \mathrm{C}$ and the coarse fraction was separated by dry sieving through a $2 \mathrm{~mm}$ sieve (Retsch AS200). The $<2 \mathrm{~mm}$ fraction was homogenised ground with an agate mortar and stored for further analysis.

\subsection{Analytical Methodologies}

2.3.1. Grain-size. Grain-size analyses were performed in the surface sediments collected in Northern Galician Rias and Shelf by dry sieving (Retsch AS-200). Sampled sediments were classified into mud, sand and gravel fractions, according to the Udden-Wentworth scale (Wentworth, 1922).

2.3.2. Carbon. Concentrations of particulate inorganic carbon (PIC) and particulate organic carbon (POC) were determined in duplicates of sediment samples in an EA1108 (Carlo Erba Instruments) elemental CNH analyzer at the University of A Coruña (SAI-UDC). POC concentration was measured directly, after removal of the carbonates by sample digestion with $\mathrm{HCl}$ at $80^{\circ} \mathrm{C}$, and $\mathrm{PIC}$ concentration quantified by the difference between total carbon (TC) and POC concentrations.

2.3.3. Mineralogy. Muscovite, quartz, riebeckite and calcite minerals were identified and quantified in the crystalline fraction of the 33 selected sediment stations (Fig. 1). Analysis was carried out in the 'Jaume Almera' Institute (CSIC) following a standard procedure (Chung, 1974). X-ray diffractions of full samples were performed in ground samples using an automatic Siemens D-500 X-ray diffractometer in the following conditions: $\mathrm{Cu} k \mathrm{ka}, 40 \mathrm{kV}, 30 \mathrm{~mA}$, and graphite monochromator. 
2.3.4. Major and minor-elements. Approximately $100 \mathrm{mg}$ of each sediment sample was completely digested with $6 \mathrm{~cm}^{3}$ of $\mathrm{HF}(40 \%)$ and $1 \mathrm{~cm}^{3}$ of Aqua Regia $\left(\mathrm{HCl}-36 \%: \mathrm{HNO}_{3}-60 \% ; 3: 1\right)$ in closed Teflon bombs at $100{ }^{\circ} \mathrm{C}$ for $1 \mathrm{~h}$ (Rantala and Loring, 1975). Subsequently, the bombs content was poured into volumetric flasks containing $5.6 \mathrm{~g}$ of boric acid and filled up with ultrapure Milli-Q water (Rantala and Loring, 1975). Metals were analyzed by flame atomic absorption spectrometry (FAAS) on a Perkin Elmer AA100 with a nitrous oxide-acetylene flame (Al) and air-acetylene flame (Fe). Iron and Al concentrations were determined with the standard additions method. The precision and accuracy of the analytical procedures was controlled through certified reference material analysis (AGV-1; USGS). The obtained concentrations (Table 1) were not statistically different from certified values (t-student; $\alpha=0.05)$.

2.3.5. Rare Earth Elements (REE) and Sc. A different mineralization procedure was done for determination of REE and Sc. The first step was the above-mentioned digestion according to Rantala and Loring (1975), which was followed by evaporation and re-dissolution with $1 \mathrm{~cm}^{3}$ of double-distilled $\mathrm{HNO}_{3}$ and $5 \mathrm{~cm}^{3}$ of ultra-pure water $(18.2 \mathrm{M} \Omega \mathrm{cm})$, heated for $20 \mathrm{~min}$ at $75^{\circ} \mathrm{C}$ and diluted to $50 \mathrm{~mL}$ with ultra-pure water. Moreover, two reagents blanks were prepared in the similar way for each batch of 20 samples. Concentrations of Sc, La, Ce, Pr, Nd, Sm, Eu, Gd, Tb, Dy, Ho, Er, Tm, Yb and Lu were determined by ICP-MS (Thermo Elemental, X-Series) equipped with a Peltier Impact bead spray chamber and a concentric Meinhard nebulizer. The experimental parameters were: forward power: 1400W; peak jumping mode; 150 sweeps per replicate; dwell time: $10 \mathrm{~ms}$; dead time: $30 \mathrm{~ns}$. The isotopes selected for the quantification of REE were either free from, or subject to minimum isobaric and polyatomic interferences (Smirnova et al., 2003). Polyatomic and isobaric interferences were minimized by setting the ratios ${ }^{137} \mathrm{Ba}^{++} /{ }^{137} \mathrm{Ba}$ and ${ }^{140} \mathrm{Ce}{ }^{16} \mathrm{O} /{ }^{140} \mathrm{Ce}$ to 0.010 under routine operating conditions. Since the abundance of $\mathrm{Ba}$, $\mathrm{Ce}$ and $\mathrm{Pr}$ in the samples was less than 700, 100 and $10 \mu \mathrm{g} \mathrm{g}^{-1}$ respectively, and the contribution of oxides relative to the analyzed ion plus the related measurement error was lower than $5 \%$, the correction for estimates of ${ }^{153} \mathrm{Eu}$ and ${ }^{157} \mathrm{Gd}$ concentrations can be avoided (Smirnova et al., 2003). 
A 7-points calibration within a range of 1 to $100 \mathrm{ppb}$ was used to quantify element concentration, using Indium as internal standard. A multi-element Quality Control (QC) solution was run every 10 samples. Coefficients of variation for metal counts $(n=5)$ varied between 0.5 and $2 \%$. Certified reference material (AGV-1, USGS) was used to control the precision of the results. Levels of REE in this material (Table 1) were not statistically different from certified concentrations (t-student; $\alpha=0.05)$. Reagent blanks always accounted for less than $1 \%$ of total concentrations in samples. Differences for sediments zones at the Northern Galician Rias were validated using a KruskalWallis test followed by a Dunn post-hoc test.

\section{RESULTS}

\subsection{Minerals}

Calcite, riebeckite, quartz and muscovite in the 33 selected samples exhibited contrasting abundance distributions (Fig. 2). Riebeckite reached $19-20 \%$ of the identified minerals in the sediments adjacent to the Cape Ortegal, while remained below $5 \%$ in samples near the Cape Estaca-de-Bares. An opposite distribution pattern was encountered for quartz, since the most abundant fraction (19-28\%) was registered in those samples, and near the Cape Ortegal concentration was below $5 \%$. The abundance of muscovite in sediments varied from $40-50 \%$ in the Ria of Viveiro, $20-30 \%$ close to the adjacent coastline, and less than $10 \%$ near the Cape Ortegal. Sediment rich in calcite was observed off-rias, increasing its content towards the continental slope (20-35\%).

\subsection{Grain size, carbon, aluminium, scandium and iron}

The grain size distribution of the collected samples revealed the predominance of sand in the shelf $(94 \pm 6 \%)$ and of fine-grained material in the innermost part of the rias and harbours (Fig.2). The POC ranged from $<1 \%$ in sandy sediments to $2-13 \%$ in the muddy sediments, while PIC varied from $3-9 \%$ in the shelf to $2-3 \%$ in the rias (not shown). Exceptions were those muddy sediments samples from the Rias of Barqueiro and Viveiro containing high quantities of shell debris (2-6\% 
$\mathrm{PIC})$ and sandy samples located around the Cape Ortegal (<2\% PIC). The distribution of Al, Sc and Fe differed considerably (Fig. 2). Aluminium varied from $0.2 \%$ in coarser material to $6.6 \%$ in the muddy sediments, although sandy sediments nearby the Cape Estaca-de-Bares presented enhanced values (2.7-4.0\%). Scandium concentrations ranged from 2 to $57 \mathrm{mg} \cdot \mathrm{kg}^{-1}$, being the highest values registered also near the same Cape $\left(33-57 \mathrm{mg} \cdot \mathrm{kg}^{-1}\right)$ and in the western of the Ria of Viveiro $\left(33-37 \mathrm{mg} \cdot \mathrm{kg}^{-1}\right)$. Iron concentrations varied from 0.3 to $6.0 \%$, being higher in sediments near Cape Ortegal (5.0-6.0\%) and lower near Cape Estaca-de-Bares (1.0-2.0\%) and the Ria of Viveiro (0.3-1.7\%).

\subsection{Rare Earth Elements}

The concentrations of total REE ( $\Sigma R E E)$ in the all sediment samples ranged from 11 to 233 mg.kg-1 (Fig.3). It accounted to total REE the La-Lu series of chemical elements, excluding the manmade element Pm. In general, muddy samples exhibited $\Sigma$ REE up to $80 \mathrm{mg} \cdot \mathrm{kg}^{-1}$. Elevated levels were found in confined muddy inner areas: Celeiro harbour (111-233 $\left.\mathrm{mg} \cdot \mathrm{kg}^{-1}\right)$, Ria of Ortigueira $\left(75-132 \mathrm{mg} \cdot \mathrm{kg}^{-1}\right)$ and Ria of Barqueiro $\left(87-130 \mathrm{mg} \cdot \mathrm{kg}^{-1}\right)$. Most of the analysed sands contained less than $70 \mathrm{mg} \cdot \mathrm{kg}^{-1}$. Relatively, high $\Sigma$ REE values $\left(40-60 \mathrm{mg} \cdot \mathrm{kg}^{-1}\right)$ were also found in sands between the Cape Ortegal and the Bares massif as well as offshore San-Ciprian massif.

Sources of Lanthanide may be emphasized if their concentrations in sediment are normalized to a reference material and reported as a relative abundance plot (Coryell et al., 1963). In the current work individual REE were normalised to European Shale (ES). In this way, the abundance variation between REE of even and odd atomic numbers is eliminated and REE pattern of average shale should parallel the average upper continental crust (Haskin and Haskin, 1966). The sum of normalized REE $\left(\Sigma R E E_{N}\right)$ highlights the neighbouring shelf of Cape Ortegal and the innermost ria zones ( $\Sigma \operatorname{REE}_{N}>6$; Fig.3) as the most lanthanide enriched in reference to European Shale.

The distribution of the ratio $(\mathrm{L} / \mathrm{H})$ between light-REE (LREE), i.e. from La to $\mathrm{Gd}$, and heavy-REE (HREE), i.e. from $\mathrm{Tb}$ to $\mathrm{Lu}$, is not related to the sediment grain-size. The most noticeable aspect (map not shown) is the contrast between low L/H ratios in sediments around Cape Ortegal (4-6) in 
comparison with the sediments of the shelf (8-11). Enhanced ratios were registered west of the Cape Estaca-de-Bares (15-16) and the inner Viveiro Ria (up to 23) due to the high contributions of La and Ce. The $L / H$ normalization with $E S\left(L_{N} / H_{N}\right)$, like before the $\Sigma R E E$, is another advantage perceiving any fractionation among the REE in the sediments due to no fractionation among REE occurred in ES. Hence, the $L_{N} / H_{N}$ (Fig.3) reflects the most importance of HREE in the adjacent area to Ortegal Complex $\left(L_{N} / H_{N}<0.8\right)$ and the LREE $\left(L_{N} / H_{N}>1.4\right)$ in the inner estuaries and near the coastal boundary between the Bares Massif and the Ollo-de-Sapo Domain in Cape Estaca-deBares.

The highest individual REE/ES ratios were registered in fine-grained sediments of the Mera and Sor estuaries (Fig.4). These sediments presented higher ratios for lighter REE, and in particular sediments from the Celeiro port. On the contrary, sediments from the western shelf of Cape Ortegal and inner rias showed lower REE/ES ratios. Sediments from the eastern shelf of Cape Ortegal presented higher ratios for heavier REE, in a clear opposition to the pattern observed for Mera and Sor estuaries.

\section{DISCUSSION}

This work illustrates how terrestrial geological formation may influence the coastal sediment geochemistry. The north Galician coast is an emblematic example due to the uniqueness of Cape Ortegal within the north-western Iberian Peninsula formations (Aparicio et al., 1987; Gil Ibarguchi et al., 1990). The influence of the lithological characteristics on the coastal sediment composition is manifested in various records. The enrichment of riebeckite and iron in sediments near the Cape Ortegal is in line with the abundance of this mineral in the complex composed by mafic and ultramafic rocks and the presence of other Fe-rich minerals (Mirre, 1990). These geochemical distributions contrast with the high abundance of quartz in sediments of the Rias of Ortigueira and Barqueiro and adjacent coastal sandy sediments. On the other hand, the massifs of San- 
Ciprian and Barqueiro made up of two-mica granite rich in muscovite (Capdevila, 1969; IGM, 1977) seem to influence the abundance of this mineral in coastal sediments.

Besides the sediment mineralogy, where calcite is the most likely reason for REE decrease in the shelf distant stations, as pointed out by Taylor and McLennan (1985) in similar areas, REE composition displays a particular significance as fingerprint of the neighbouring geological features. The low concentration of $\Sigma R E E$ and high values of $\Sigma R E E_{N}$ in sediments around Cape Ortegal shows undoubtedly the influence of the Ortegal Complex in the continental shelf (Fig.3). Two zones can be discerned around the Cape. The western sediments are under ultramafic rocks influence and display low $\Sigma R E E$ content and low $L / H$ ratio. The low $L / H$ and $L_{N} / H_{N}$ ratios derived from LREE-depleted alloctonous eclogites of the Ortegal Complex (Bernard-Griffiths et al., 1985). The eastern end-Cape is slightly richer in LREE due to partial eclogites and basic granulites from Ortegal Complex, which is in line with the findings of Peucaut et al. (1990). These L/H ratios are below those found in the Ria of Vigo (Table 3), due to presence of LREE-enriched Galiñeiro orthogneissic Complex (Prego et al., 2009) and to the supply of HREE $\left(L_{N} / H_{N}<0.8\right.$, Fig.3; $(\mathrm{La} / \mathrm{Yt})_{\mathrm{N}} \approx 0.3$, Table 3) from the Ortegal Complex. The increase of $\Sigma$ REE concentration eastward the Cape Ortegal is in line with the sequence of the lithological features of the Bares Massif (granodiorites) - Barqueiro and San-Ciprian Massifs (granites) - Ollo-de-Sapo Domain (metamorphic). Nevertheless, their REE/ES values (Fig.4) are not distinguishable as result of the variability, except for some lanthanide elements of Bares Massif. This lack of discernibly may be partially influenced by a mixture of detrital weathering fractions derived from different land sources coupled with a removal of dissolved REE from the water. Planktonic uptakes, coprecipitation with iron hydroxides, and salt induced coagulation of colloids have been suggested as the removal mechanism (Nozaki, 2003). In the Northern Galician shelf REE pattern is more discernible than in the Loire and Gironde estuarine sediments where REE did not permit to discriminate between the possible continental sources (Joaunneau et al., 1998). The sediments of northern Galician coast also show a deficit of REE compared with sediments of the west coast of 
the Iberian Peninsula at Douro and Galicia mud patches (Joaunneau et al., 2002; Araújo et al., 2007) and at east coast of the Cantabrian Sea at the American and Aquitania shelves (Joauneau et al., 1998).

In the innermost zones of the Rias of Ortigueira and Barqueiro and their fluvial end-members, the sediment source is associated with metamorphic rocks from Ollo-de-Sapo Domain (Sor and Mera Basins) and Moeche Unit (Mera Basin). The sediments from these two estuarine systems exhibited similar REE/ES patterns (Fig.4), where values were up to five times to those found in the rias and shelf. This pattern indicates that fine grained sediments are richer in REE than sandy sediments. For example, sandy sediments from the Landro estuary and the Ria of Viveiro, both coming from the same granitic type massifs, have a similar REE fingerprint. Otherwise, fine sediments from the Celeiro fishing port located in the inner of the Ria of Viveiro, display the fingerprint of fine sediments from Mera and Sor estuaries. The exception was found for La and redox-sensitive Ce that doubled the concentration in this area and it could be associated to shipyard activities and mud sediments. Moreover, the positive anomaly of Gd normalized with ES (Fig.4) observed in sediments of the above-mentioned three estuarine and dock areas may presumably due to the lower stabilities of $\mathrm{Gd}$ complexes is seawater compared to those of their respective neighbours in the REE series (Byne and Kim, 1990; Kim et al., 1991).

Unlike the deficit of LREE in coastal sediments, values found in the Landro and Mera estuaries were comparable with levels found in the inner sediments of the Ria of Vigo (Prego et al., 2009) and Miño estuary (Gouveia et al, 1993; Alvarez-Iglesias et al., 2009). However, LHREE contents in these two estuaries were lower $\left(\mathrm{L}_{N} / \mathrm{H}_{N}>1.4\right.$, Fig.3; $(\mathrm{La} / \mathrm{Yb})_{N} \approx 1.0$, Table 3) than those found for the inner Ria of Vigo and Miño estuary. The increase of REE content in fine particles of these tributaries may be favoured by absorption-desorption processes during the estuarine mixing (Sholkovitz and Szymczac, 2000; Nozaki et al., 2000; Yang et al., 2002; Marmolejo-Rodriguez et al., 2007; Hannigan et al., 2010). Since fine grained particles are mainly settled in marshes and 
innermost parts, a minor contribution of REE fluvial end-members to the continental shelf can thus be expected.

\section{CONCLUSION}

The distribution of REE in the northern Galician coast is highly depending on the neighbouring lithological pattern. The mafic and ultramafic rocks of the Ortegal Complex, as well as the metamorphic rocks Ollo-de-Sapo autochthonous domain and the granitic massifs of San Ciprian and Barqueiro, appears to determine the REE pattern in coastal sediments, where the Ortegal Complex is the local source of HREE. This predominance also results from the low fluvial loads, since fine particles with a different REE signature are accumulated in the innermost parts of the Rias. These results point to the contrasting situation between northern and the western Galician coast where fluvial discharges influence the Miño and Duero mud patches. A similar situation was found in the shelf fine deposit zones in the Loire, Gironde and Adour plumes. Lanthanides can thus provide a useful tool to follow the sediment pathway in the land-sea boundary zones denoting continental geochemical imprint accordingly to the existing hydrological and geological conditions.

Acknowledgements: Authors thank the crew of the R/V Mytilus (CSIC) and R/V Lura (IEO) for their kind assistance during field work; Dr. S. Giralt of Institute of Earth Sciences Jaume Almera (CSIC) for the mineralogical determinations; and Ms. A. Rodríguez-Riveiros (IIM-CSIC) for her technical assistance in the analysis and data processing. This paper is a contribution to the Spanish LOICZ program and was supported by the CICYT project 'Influence of meteorological forcing, land geochemistry and estuarine zone in the hydrodynamic, biogeochemical cycle of trace metal and rare earth and plankton transport in the Northern Galician Rias (NW Spain)', ref. CTM2007-62546C03/MAR, in cooperation with the Spanish-Portuguese Action ref. 2007PT0021. 


\section{REFERENCES}

Alvarez, I., Ospina-Alvarez, N, deCastro, M., Varela, M., Gomez-Gesteira, M., Prego, R., 2010. Poleward intrusion in the northern Galician shelf. Estuar. Coastal Shelf Sci. 87, 545-552.

Álvarez-Iglesias, P., Araújo, M.F., Gouveia, A., Drago, T., 2009. Geochemical analysis of Minho Estuary sedimentary record and its contribution to palaeoenvironmental evolution. J. Radioanal. Nucl. Chem. $281,237-240$.

Aparicio, A., Sánchez Cela, V., Cacho, L.E., 1987. Petrological and geochemical considerations of the Cabo Ortegal Complex (NW Spain). Rev. Real Acad. Cienc. Zaragoza 42, 131-162.

Araújo M.F., Jounneau J.M., Valério, P., Barbosa, T., Gouveia, A., Oliveira, A., Rodrigues A., Dias, J.M.A., 2002. Geochemical tracers of northern Portuguese estuarine sediments on the shelf. Prog. Oceanogr. $52,277-297$.

Araújo, M.F., Corredeira, C., Gouveia, A., 2007. Distribution of rare elements in sediments of the Northwestern Iberian Continental Shelf. J. Radioanal. Nucl. Chem. 271, 255-260.

Bayon, G., German, C.R., Burton, K.W., Nesbitt, R.W., Rogers, N., 2004. Sedimentary Fe-Mn oxy-hydroxides as paleoceanographic archives and the role of aeolian flux in regulating oceanic disolved REE. Earth Planet. Sci. Lett. 224, 477-492.

Bernard-Griffiths, J., Peucat, J., Cornichet, J., Iglesias Ponce de León, M., Gil-Ibarguchi, J.I., 1985. U-Pb, Nd Isotope and REE geochemistry in eclogites from the cabo Ortegal complex, Galicia, Spain: An example of REE immobiliy conseving MORB-like patterns during high-grade metamorphism. Chem. Geol. 52, 217225.

Borrego, J., López-González, N., Carro, B., Lozano-Soria, O., 2004. Origin of anomalies in light and middle REE in sediments of an estuary affected by phosphogypsum wastes (south-western Spain). Mar. Pollut. Bull. 49, 1045-1053.

Bortnikov, N.S., Gorelikova, N.V., Korostelev, P.G., Gonevchuk, V.G., 2008. Rare earth elements in tourmaline and chlorite from tin-bearing assemblages: Factors controlling fractionation of REE in hydrothermal systems. Geol. Ore Deposits 50, 445-461.

Byne, R.H., Kim, K.-H., 1990. Rare Earth elements scavenging in seawater. Geochim. Cosmochim. Acta 54, 2645-2656.

Caetano, M., Prego, R., Vale, C., dePablo, H., Marmolejo-Rodríguez, J., 2009. Evidence for early diagenesis of rare earth elements and metals in a transition sedimentary environment. Mar. Chem. 116, 36-46.

Capdevila, R., 1969. Le métamorphisme régional progressif et les granites dans le segment hercynien de Galice nord-oriental (NW de l'Espagne). Ph. Thesis, University of Montpellier (France), $430 \mathrm{pp}$.

Chaillou, G., Anschultz, P., Lavaux, G., Blanc, G., 2006. Rare earth elements in the modern sediments of the Biscay (France). Mar. Chem. 100, 39-52.

Chung, F., 1974. Quantitative interpretation of X-ray diffraction patterns of mixtures: II. Adiabatic principles of X-ray diffraction analysis of mixtures. J. Appl. Crystallog. 7, 526-531. 
Coryell, C.G., Chase, J.W., Winchester, J.W., 1963. A procedure for geochemical interpretation of terrestrial rare-earth abundance patterns. J. Geophys. Res. 68, 559-566.

Dubinin, A.V., 2004. Geochemistry of rare earth elements in the ocean. Lithol. Mineral Res. 39, 289-307.

Elderfield, H., Upstillgoddard, R., Sholkovitz, E.R., 1990. The rare-earth elements in rivers, estuaries, and coastal seas and their significance to the composition of ocean waters. Geochim. Cosmochim. Acta 54, 971-991.

Evans, G., Prego, R., 2003. Rias, estuaries and incised valleys: is a ria an estuary? Mar. Geol. 196, 171-175.

Gent, R., Menéndez Álvarez, M., García Iglesias, J., Taraño Álvarez, J., 2005. Offshore occurrences of heavymineral placers, Northwest Galicia, Spain. Mar. Georesources Geotechnol. 23, 39-59.

Gil-Ibarguchi, J.I., Mendia, M., Girardeau, J., Peucat, J.J., 1990. Petrology of eclogites and clinopyroxenegarnet metabasites from the Cabo Ortegal Complex (northwestern Spain). Lithos 25, 133-162.

Goldberg, E.D., Koide, M., Schmitt, R., Smith, R., 1963. Rare-earth distributions in the marine environment. J. Geophys. Res. 68: 4209-4217.

Gouveia, M.A., Araújo, M.F.D., Dias, J.M.A., 1993. Rare earth element distribution in sediments from the Minho river and estuary (Portugal) - a preliminary study. Chem. Geol. 107, 379-383.

Hannigan, R., Dorval, E., Jones, C., 2010. The rare earth element chemistry of estuarine surface sediments in the Chesapeake Bay. Chem. Geol. 272, 20-30.

Haskin, L.A., Gehl, M.A., 1962. The rare-earth distribution in sediments. J. Geophys. Res. 67: 2537-2541.

Haskin, M.A., Haskin L.A., 1966. Rare-earths in European shales: A redetermination. Science 154, 507-509.

IGME, 1977. Mapa geológico de España. Hoja de Cariño (1:50.000), Instituto Geológico Minero de España, Madrid.

Joaunneau, J.-M., Weber, O., Grousset, F.E., Thomas, B., 1998. Pb, Zn, Cs, Sc and rare earth elements as tracers of the Loire and Gironde particles on the Biscay shelf (SW France). Oceanol. Acta 21, 233-241.

Joaunneau, J.-M., Weber, O., Drago, T., Rodrigues, A., Oliveira, A., Dias, J.M.A., Garcia, C., Schmidt, S., Reyss, J.L., 2002. Recent sedimentation and sedimentary budgets on the western Iberian shelf. Prog. Oceanogr. $52,261-275$.

Kim, K.-H-, Byne, R.H., Lee, J.H., 1991. Gadolinium behavior in seawater: a molecular basis for gadolinium anomalies. Mar. Chem. 36, 107-120.

Leybourne, M., Johannesson, K., 2008. Rare earth elements (REE) and yttrium in stream waters, stream sediments, and Fe-Mn oxyhydroxides: Fractionation, speciation, and controls over REE $+\mathrm{Y}$ patterns in the surface environment. Geochim. Cosmochim. Acta 72, 5962-5983.

Lorenzo, F., Alonso, A., Pagés, J.L., 2007. Erosion and accretion of beach and spit systems in northwest Spain: A response to human activity. J. Coast. Res. 23, 834-845.

Kulaksız, S., Bau, M., 2007. Contrasting behaviour of anthropogenic gadolinium and natural rare earth elements in estuaries and the gadolinium input into the North Sea. Earth Planet. Sci. Lett. 260, 361-371.

Marmolejo-Rodríguez, A.J., Prego, R., Meyer-Willerer, A., Shumilin, E., Sapozhnikov, D., 2007. Rare earth elements in iron oxy-hydroxide rich sediments from the Marabasco River-Estuary system (Pacific coast of Mexico). REE affinity with iron and aluminium. J. Geochem. Explor. 94, 43-51. 
Mirre, J.C., 1990. Guia dos minerais de Galicia, Editorial Galaxia, Vigo.

Munksgaard, N.C., Lim, Kezia, Parry, D.L., 2003. Rare earth elements as provenance indicators in North Australian estuarine and coastal marine sediments. Est., Coastal Shelf Sci. 57, 399-409.

Nozaki, Y., Lerche, D., Alibo, D.S., Snidvongs, A., 2000. The estuarine geochemistry of rare earth elements and indium in the Chao Phraya River, Thailand. Geochim. Cosmochim. Acta 64, 3983-3994.

Nozaki, Y., 2003. Rare Earth elements and their isotopes in the ocean. In: Steele, J.H., Thorpe, S.A., Turekian, K.K. (Eds.), Encyclopedia of Ocean Sciences. Academic Press, San Diego, pp. 2354-2366.

Olivarez, A.M., Owen, R.M., 1989. REE/Fe variations in hidrotermal sediments: implications for the REE content of seawater. Geochim. Cosmochim. Acta 53, 757-762.

Olmez, I., Sholkovitz, E.R., Hermann, D., Eganhouse, R.P., 1991. Rare earth element geochemistry of southern California: a new anthropogenic indicator. Environ. Sci. Technol. 25, 310-316.

Ortega, L.A., Gil-Ibarguchi, J.I., 1990. The genesis of Late Hercynian granitoids from Galicia (northwestern Spain): inferences from REE studies. J. Geol. 98, 189-211.

Ospina-Alvarez, N., Prego, R., Álvarez, I., deCastro, M., Álvarez-Ossorio, M.T., Pazos, Y., Campos, M.J., Bernárdez, P., Gómez-Gesteira, M., Varela, M., 2010. Oceanographical patterns during an upwellingdownwelling event in the northern Galician Rias. Comparison with the whole ria system (NW of Iberian Peninsula). Cont. Shelf Res. 30, 1362-1372.

Peucat, J.J., Bernard-Griffiths, J., Dallmeyer, R.D., Menot, P., Cornichet, J., Iglesias Ponce de Leon, M., GilIbarguchi, J.I., 1990. Geochemical and geochronological cross-section of the deep Hercynian crust: the Cabo Ortegal high-pressure nappes (NW Spain). Tectonophysics 177, 263-292.

Pin, C., Paquete, J.L., Santos-Zalduegui, J. F., Gil-Ibarguchi, J.I., 2002. Early Devonian suprasubduction-zone ophiolite related to incipient collisional processes in the Western Variscan Belt: the Sierra de Careón Unit, Ordenes Complex, Galicia. Geol. Soc. Am. Bull. 364, 57-71.

Piper, D.Z., 1974. Rare earth elements in the sedimentary cycle: a summary. Chem. Geol. 14, 285-304.

Prego, R., Boi, P., Cobelo-García, A., 2008. The contribution of total suspended solids to the Bay of Biscay by Cantabrian Rivers (northern coast of the Iberian Peninsula). J. Marine Syst. 72, 342-349.

Prego, R., Marmolejo, J., Caetano, M. Vale, C., 2009. Rare earth elements in sediments of the Vigo Ria (NW Iberian Peninsula). Cont. Shelf Res. 29, 896-902.

Protano, G., Riccobono, F., 2002. High contents of rare earth elements (REEs) in stream waters of a Cu-PbZn mining area. Environ. Pollut. 117, 499-514.

Ramesh R., Ramanathan A.L., James R.A., Subramanian V., Jacobsen S.B., Holland H.D., 1999. Rare earth elements and heavy metal distribution in estuarine sediments of east coast of India. Hydrobiologia 397, 89-99.

Rantala R., Loring, D., 1975. Multi-element analysis of silicate rocks and marine sediments by atomic absorption spectrophotometry. Atomic Absorption Newsletter 14, 117-120.

Ridgway J., Breward N., Langston W.J., Lister R., Rees J.G. Rowlatt, S.M., 2003. Distinguishing between natural and anthropogenic sources of metals entering the Irish Sea. Appl. Geochem. 18, 283-309. 
Ronov, A.B., Balashov, Y.A., Migdisov, A.A., 1967. Geochemistry of the rare earths in the sedimentary cycle. Geochem. Int. 4, 1-17.

Sholkovitz, E.R., 1993. The geochemistry of rare earth elements in the Amazon River estuary. Geochim. Cosmochim. Acta 57, 2181-2190.

Sholkovitz, E., Szymczak R., 2000. The estuarine chemistry of rare earth elements: comparison of the Amazon, Fly, Sepik and the Gulf of Papua Systems. Earth Planet. Sci. Lett. 179, 299-309.

Smirnova, E.V., Fedorova, I.N., Sandimirova, G.P., Petrov, L.L., Balbekina, N.G., Lozhkin, V.I., 2003. Determination of rare earth elements in black shales by inductively coupled plasma mass spectrometry. Spectrochim. Acta B: Atomic Spectroscopy 58, 329-340.

Taylor, S.R., McLennan, S.M., 1985. The Continental Crust: Its Composition and Evolution. Blackwell, Oxford. Torre-Enciso, E., 1958. Estado actual del conocimiento de las rias gallegas, in: Homenaxe a X.R. Otero Pedrayo, Editorial Galaxia, Vigo, pp. 237-250.

Vital, H., Stattegger, K., Garbe-Schonberg, C.D., 1999. Composition and trace-element geochemistry of detrital clay and heavy-mineral suites of the lowermost Amazon River: a provenance study. J. Sediment. Res. A 69, 563-575.

Wentworth, C.K., 1922. A scale of grade and class terms for clastic sediments. J. Geol. 30, 377-392.

Wildeman, T.R., Haskin, L.A., 1963. Rare earth elements in ocean sediments. J. Geophys. Res. 70, 29032910.

Yang, S.Y., Jung, H.S., Choi, M.S., Li, C.X., 2002. The rare earth element compositions of the Changjiang (Yangtze) and Huanghe (Yellow) river sediments. Earth Planet. Sci. Lett. 201, 407-419.

Xu, Z., Lim, D., Choi, J., Yang, S., Jung, H., 2009. Rare earth elements in bottom sediments of major rivers around the Yellow Sea: implications for sediment provenance. Geo-Marine Lett. 29, 291-300.

\section{Figure Captions}

Figure 1. Detailed sketch map showing the main geological units and the lithological characteristics of the northern coast of Galicia. Dots indicate the position of the surface sediment sampling. White dots specify the samples where mineralogical analyses were conducted. Lithology map was available from the Spatial Data Infrastructure of Galicia http://sitga.xunta.es/sitganet/index.aspx?lang=gl

Figure 2. Distribution of relevant minerals and metals in surface sediments associated to the main lithological characteristics of the northern coast of Galicia. 
Figure 3. Distribution of rare earth elements, without ( $\mathrm{REE})$ and with $\left(\Sigma \mathrm{REE}_{\mathrm{N}}\right)$ ES normalization and its REE light-heavy normalized relationship $\left(L_{N} / H_{N}\right)$ in surface sediments of the Northern Galician Rias and their neighbouring shelf.

Figure 4. Patterns of REE fingerprints, normalized to European Shale, of the surface sediments of the Northern Galician Rias and their neighbouring shelf. 
Latitude W (UTM, m)

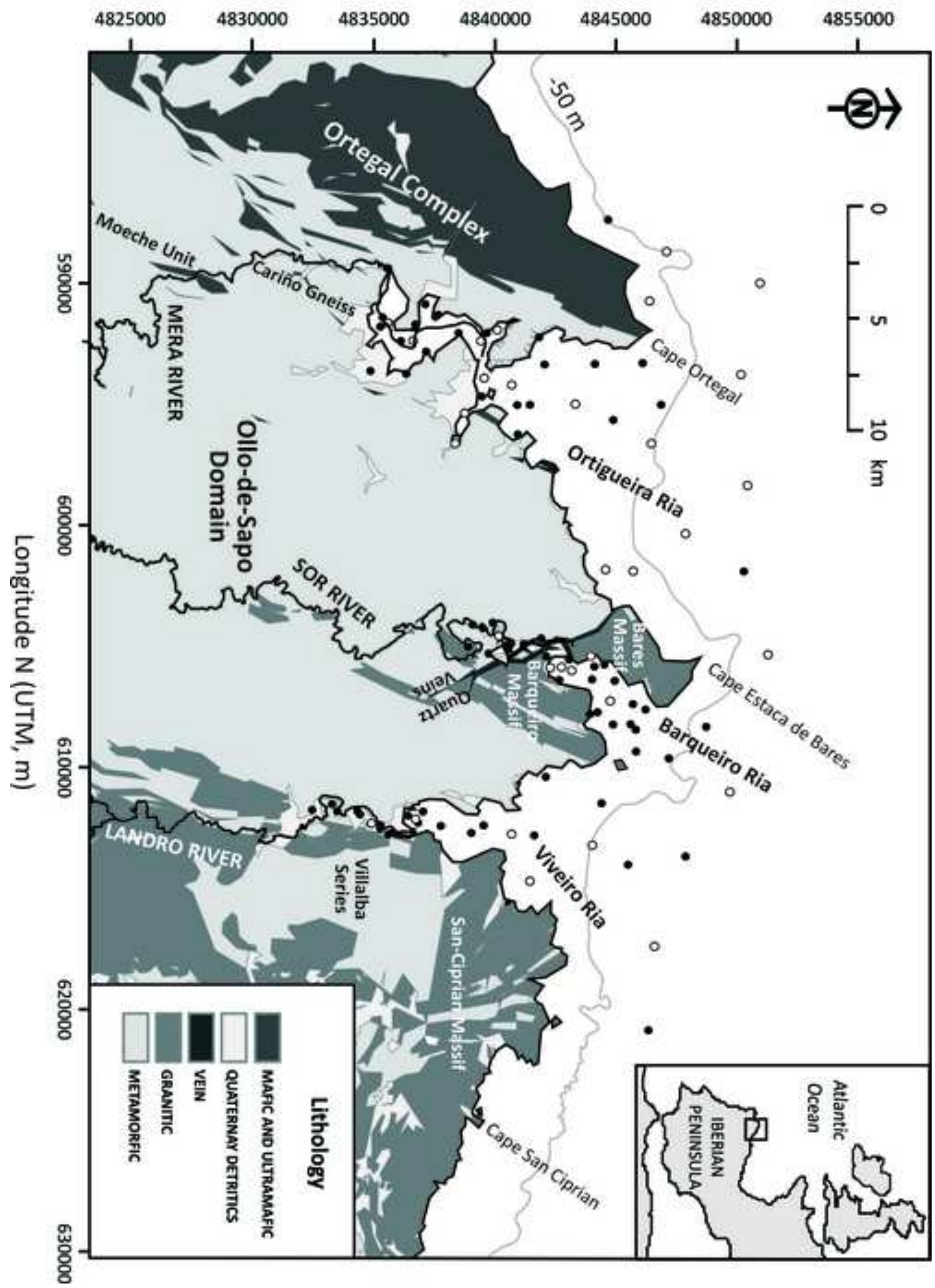



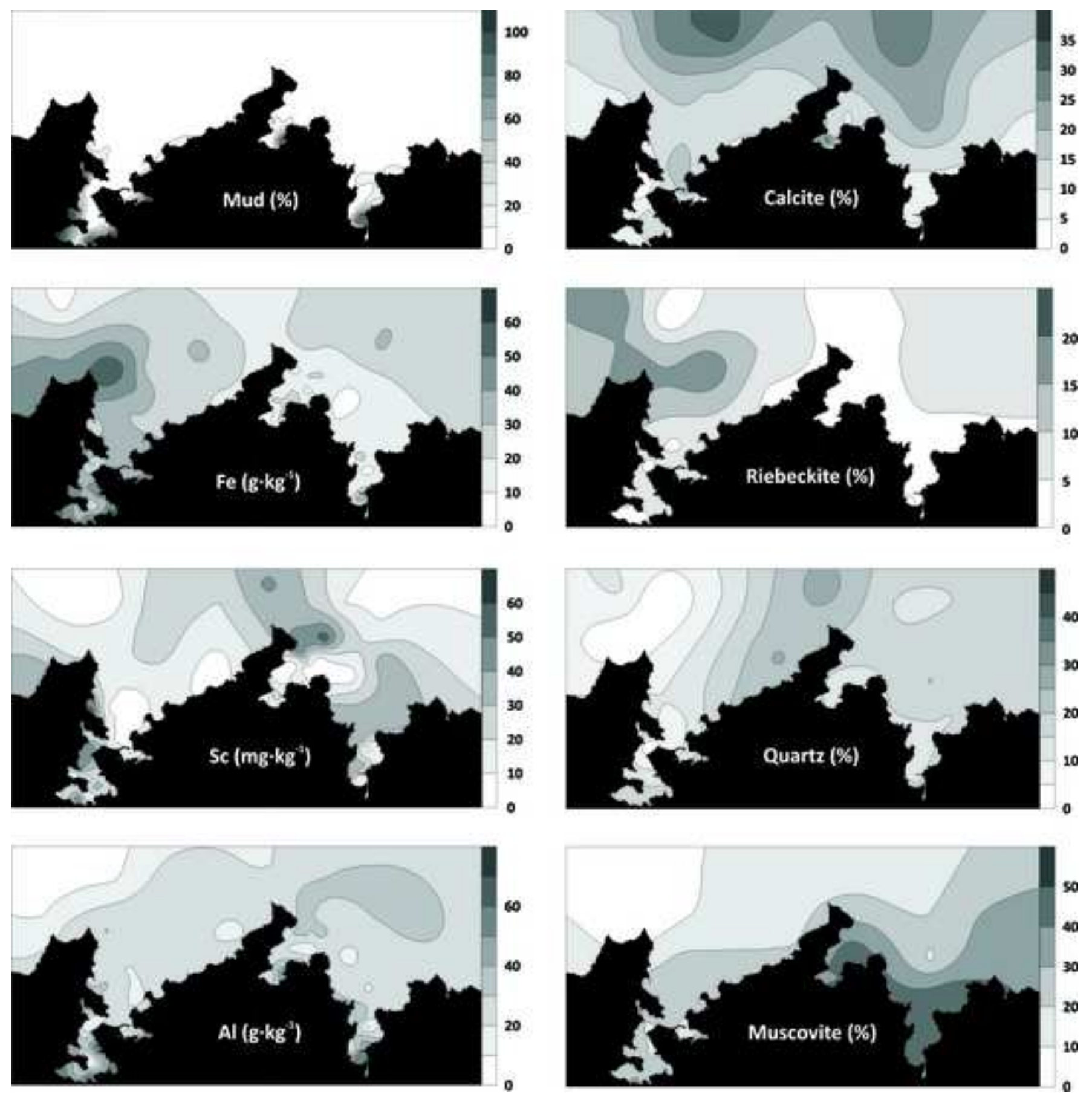

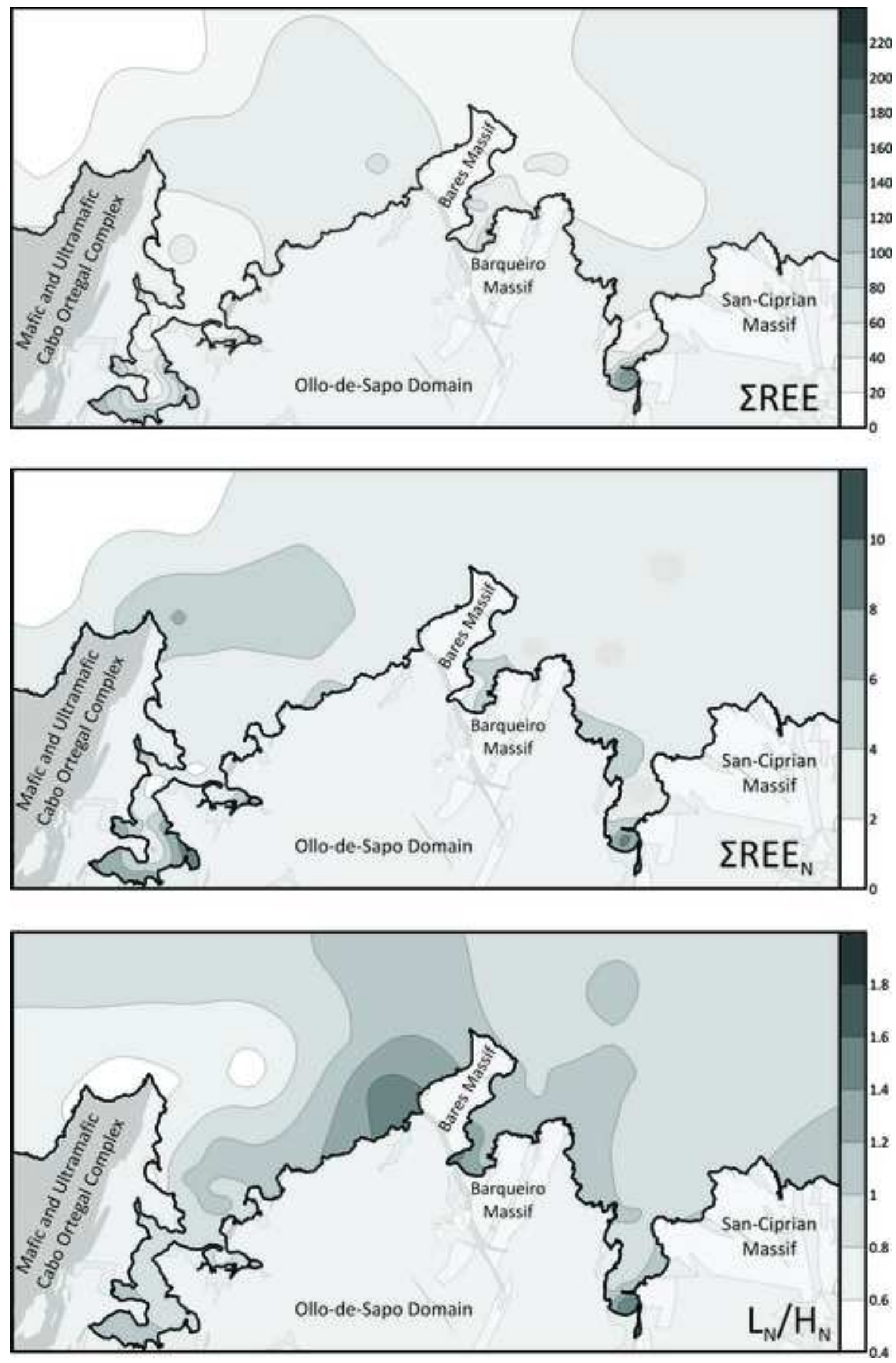
REE/ES

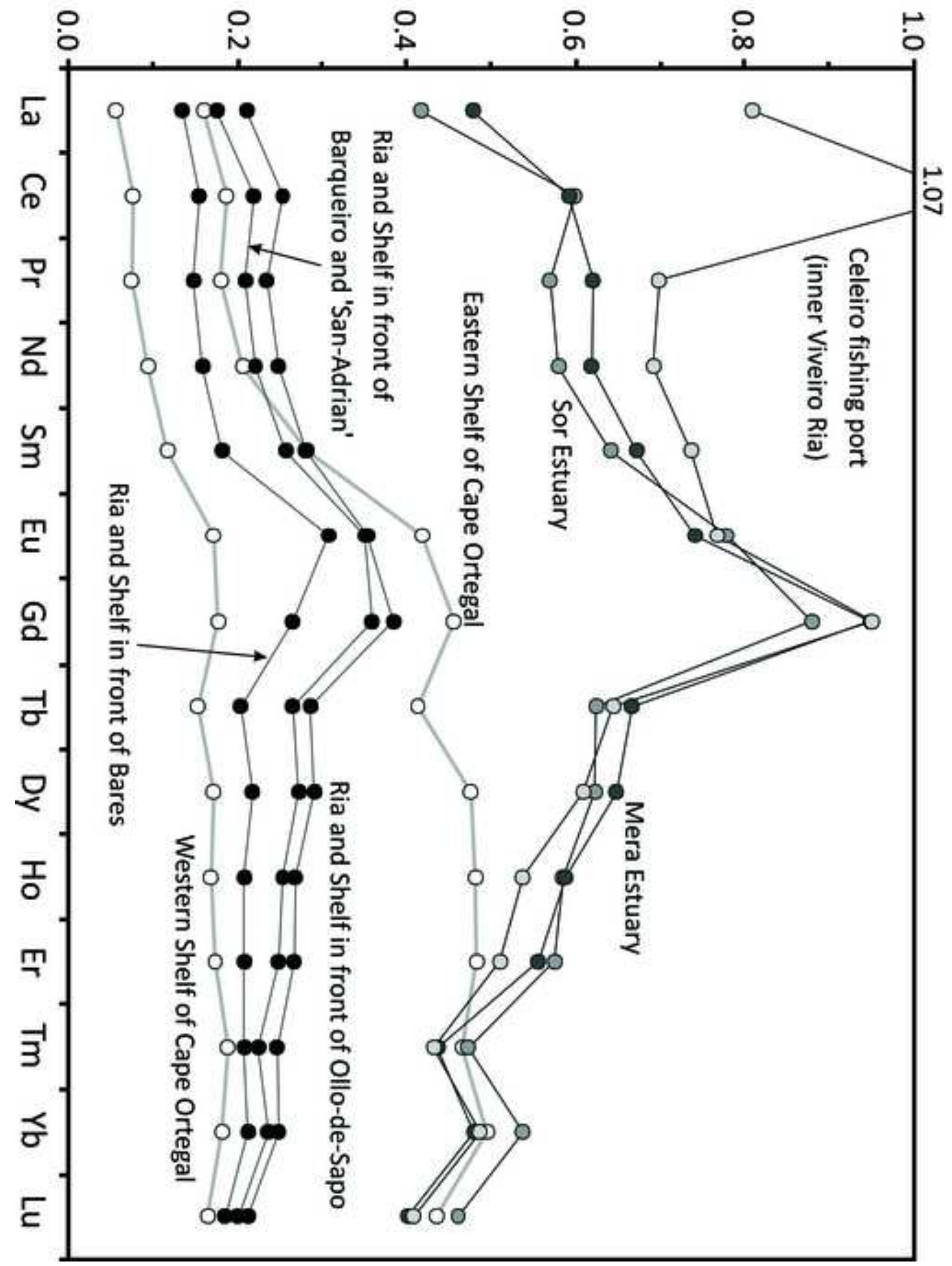




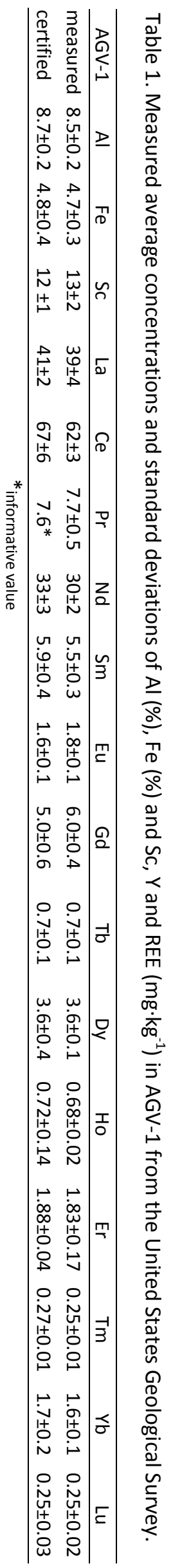


Table 2. Concentration of rare earth elements (REE) measured in superficial sediment of the Northern Galician Ras and its neighbouring continental shelf. REE units are in $\mathrm{mg} \cdot \mathrm{kg}^{-1}$ while $\mathrm{Al}$ and $\mathrm{Fe}$ in $\%$.

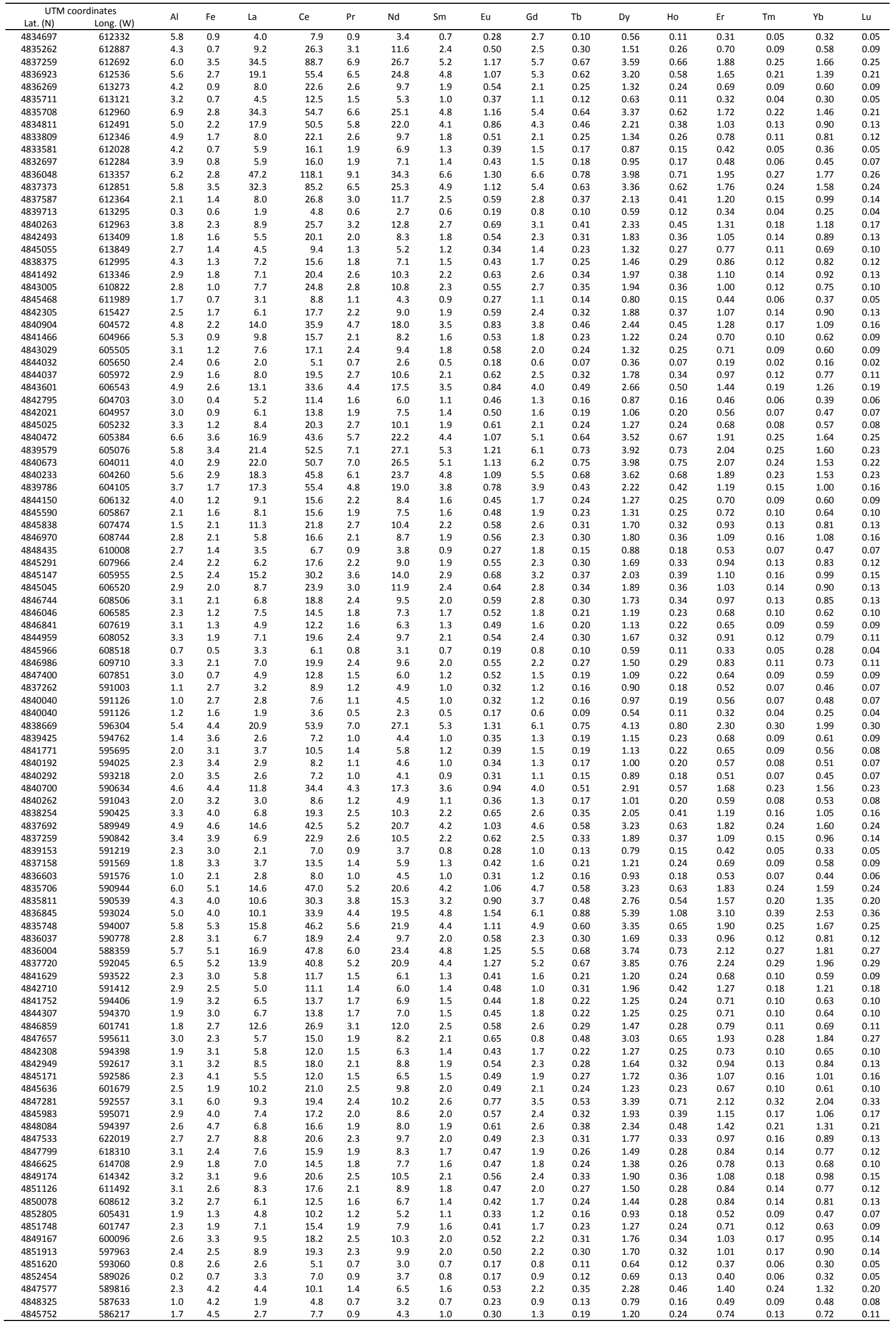




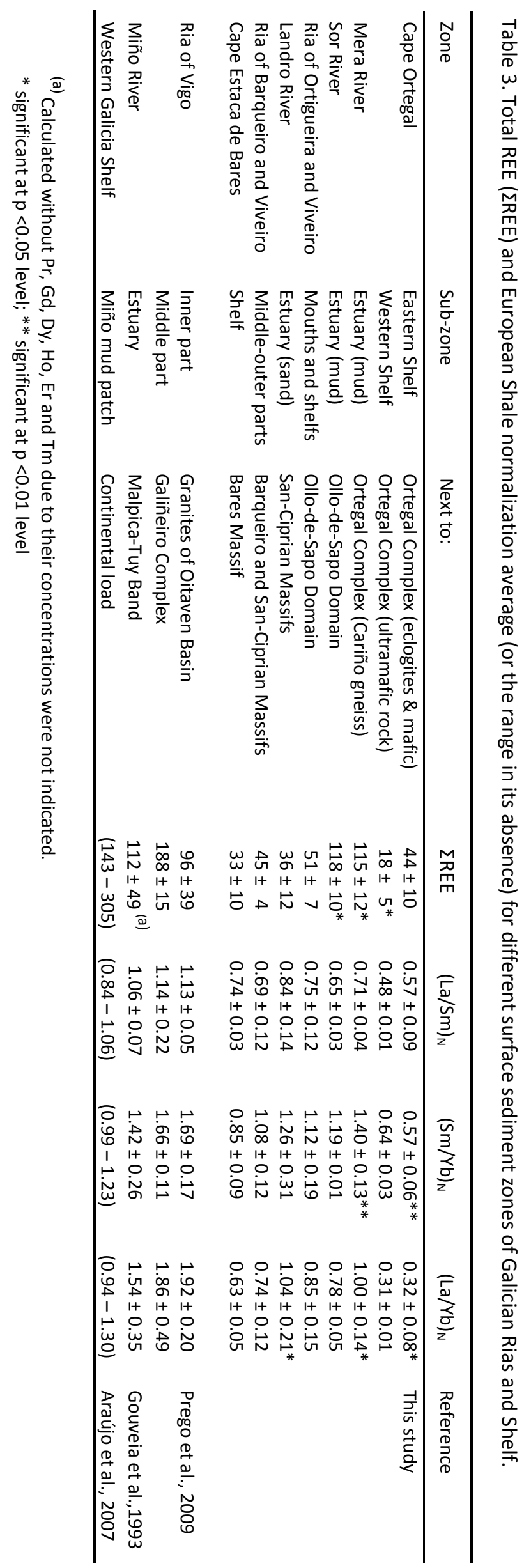

